\title{
PROPAGATION OF THREE MUSHROOMS GENERA IN SUBMERGED CULTURE OF MANGO STONE INFUSION
}

\author{
El-Makhzangy, A. \\ Agro-industry Dept. Institute of Efficient Productivity (IEP), \\ Zagazig Univ., Zagazig, Egypt
}

\begin{abstract}
Factors affecting the production of mushroom mycelium from Agaricus bisporus, Pleurotus ostreatus and Pholiota aegerita grown in mango stone infusion for 7 days were studied. The optimum conditions enhancing the economic coefficient (EC) of mushroom mycelium were 25,30 and $20^{\circ} \mathrm{C}$ for incubation temperature, 4.0, 4.5 and 5.5 for pH values, 300 r.p.m. for shaking rate and $25: 1$ for $\mathrm{C} / \mathrm{N}$ ratio in case of Agaricus bisporus, Pleurotus ostreatus and Pholiota aegerita with high EC of 66.8, 51.9 and 63.9, respectively. In comparison under these optimum conditions, molasses media (as control) reflected lowered EC than that of mango stone infusion. The dry mycelium of $A$. bisporus showed a higher protein and fat contents than Pleurotus ostreatus and Pholiota aegerita. Inorganic elements, $\mathrm{Mg}, \mathrm{Ca}, \mathrm{Na}, \mathrm{K}, \mathrm{Cu}, \mathrm{Fe}, \mathrm{Mn}, \mathrm{Zn}, \mathrm{Pb}$ and $\mathrm{Cd}$ were also detected.
\end{abstract}

Keywords: fermentation, mushroom, food wastes.

\section{INTRODUCTION}

Food industries produce large amount of various types of wastes causing environmental pollution. Various methods for the utilization and recovery of by-products, were reviewed by many investegators (Joshi \& Joshi, 1990, Ballero, 1991, Kuzmanova et al., 1991, Ethiraj \& Suresh, 1992, Zhu \& Hi 1999). There is an increasing demand for natural ingredients and flavourings in food industry. However, submerged germentation is a fast and attractive technological process for production of highly flavoured mushroom biomass and is otherwise applied by either traditional or laboratory procedures (Hadar \& Dosoretz, 1991 and Allan \& Kennedy, 1997).

Mushroom mycelium was found to have approximately the same nutritive value as fodder yeast when grown in waste products of the citrus industry, molasses and waste sulfite (Kuzmanova et al., 1991 and Zhu \& Hi, 1999). Cirillo (1960) suggested that, mushroom mycelium produced in waste sulfite liquor can be used as a protein supplement for human food or for animal feed.

Litchfield et al. (1963) showed that, morel mushroom mycelium could be grown in submerged culture with glucose, maltose, lactose or wastes containing these sugars as substrate. Sugihara \& Humfeld (1954) reported that, excellent yields of mushroom mycelia were produced when mycelia were grown on orange juice, citrus press water and chemically defined media.

Mushroom makes a very welcomed addition to the diet in certain areas of the world and is considered to be the most favorable fungus for its pleasant flavour, high nutritive value and medical effect (Chiang et al., 1986, Anon, 1994, Johl et al., 1997). Furthermore, Kuniori et al. (1976) reported that the quality of mushroom protein is valued, better than that of cereal grains and legumes because all the nine essential amino acids are present. In addition, mushroom is also a source of some nutrients such as phosphorous, iron, thiamine (Vit. $\mathrm{B}_{1}$ ), riboflavin (Vit. $\mathrm{B}_{2}$ ) and niacin (Kalac \& Svoboda, 2000).

This investigation aimed to propagate three of some common edible mushroom mycelia in a submerged culture prepared from mango stone infusion which could be used in a future study as food supplements or flavouring materials.

\section{MATERIALS AND METHODS}

\section{Materials :}

Fungi: The mushroom strains used in this study were Agaricus bisporus MIRCEN 180 and Pleurotus ostreatus MIRCEN 201, obtained from Microbiological Resource Centre (MIRCEN), Ain Shams University, Egypt. 
Pholiota aegerita was kindly offered in form of spawn from AZ. AGR. Paolo Costa, Produzione Micelio E Funghi, Italy.

The spawn of Pholiota aegeritai was cultured on wood dust as described by Subba (1989). Tissue culture technique was carried out to select fresh pure mature mushroom. Gentle washing under running water is necessary to remove surface dirt. The surface is also wiped gently with $70 \%$ alcohol. Using a sterile scalpel, a small slit from the bottom of the mushroom was removed. Mushroom was cut into two halves avoiding touching the inner surface. A few pieces of tissue from the center of the mushroom was transferred to malt extract agar plates. The cultures were incubated for few days. Some tiny bits of the mycelia were transferred to another agar plates.

Wastes and by-products: Mango stone wastes were obtained from El-Nasr for Food Preservation "Kaha", Abo-Kaber factory, Sharkia, Egypt.

Sugar cane molasses was obtained from Egyptian Sugar and Distillery Company (Hawamdia Factory), Egypt.

\section{Methods:}

Preparation of standard inoculum: All inocula were prepared by the transference of mycelia bits from the agar slants to $250 \mathrm{ml}$ Erlenmeyer flasks containing $40 \mathrm{ml}$ of $5 \%$ malt extract broth and then were incubated at $25^{\circ} \mathrm{C}$ for 10 days. The whole contents of the flasks were then blended for $30 \mathrm{sec}$, in a sterile waring blender. The resulted homogeneous suspensions were centrifuged at 2000 $\mathrm{rpm}$ for $5 \mathrm{~min}$. and resuspended in $40 \mathrm{ml}$ sterile distilled water (Falanghe, 1962).

Fermentation process: For the preparation of the molasses medium (as control), the molasses was dissolved in distilled water to give $5 \%$ sugar concentration, then $4.0 \mathrm{~g}$ ammonium sulfite, $0.1 \mathrm{~g}$ potassium phosphate, $0.5 \mathrm{~g}$ magnesium sulfate and $0.003 \mathrm{~g}$. ferrous sulfate were added to one litre of the diluted molasses.

From the other hand, mango stone infusion was prepared by dipping $5 \mathrm{Kg}$ of mango stones in 10 litres of hot water $\left(70^{\circ} \mathrm{C}\right.$ for 7 hrs. with $15 \mathrm{~min}$. interval stirring), then filtered. Ammonium tartrate $1.1 \mathrm{~g} / 1000 \mathrm{ml}$ were added as nitrogen source. All the media were sterilized in $500 \mathrm{ml}$ flasks where each was containing $200 \mathrm{ml}$ of medium. Each flask was inoculated with $2 \mathrm{ml}$ of the prepared standard inoculum and incubated under different experimental conditions.

Chemical analysis: Moisture, total solids, fat, crude fiber and ash contents were determined according to A.O.A.C (1980). Atomic absorption Unicam 969 spectrometer was used for inorganic element determination. Reducing and non reducing sugars were estimated according to the method described by Somgyi (1945). Semi-Kjeldahl method was used for crude protein estimation. Yield Coefficient (YC) and Economic Coefficient (EC) were estimated according to the following equations as described by Falanghe (1962).

$\mathrm{YC}=(\mathrm{mg}$ mushroom mycelium formed/mg sugar utilized) $\times 100$

$\mathrm{EC}=(\mathrm{mg}$ mushroom mycelium formed/mg total sugars) $\times 100$

\section{RESULTS AND DISCUSSION}

Several chemical constituents of mango stone infusion were studied for their possible application for production of mushroom mycelia. Table (1) shows the chemical components of mango stone infusion prepared by dipping one part of mango stones in two parts of water.

Table 1: Main components of mango-stone infusion

\begin{tabular}{l|c}
\hline \multicolumn{1}{c|}{ Items } & $\begin{array}{c}\text { Mango stone } \\
\text { infusion }\end{array}$ \\
\hline Total solids (\%) & 6.24 \\
Total sugars (\%) & 4.43 \\
Reducing sugars (\%) & 4.1 \\
Non-reducing sugars (\%) & 0.33 \\
Total acidity (as citric acid \%) & 0.13 \\
pH & 5.0 \\
Protein \% (N x 6.25) & 0.4 \\
Ash (\%) & 0.52 \\
\hline
\end{tabular}

Accordingly, from these values, there is a possibility to use this infusion in a fermentation process for mushroom mycelia production.

Fig. (1) shows the effect of incubation temperature on Economic Coefficient (EC) of the produced mushroom mycelium grown in mango stone infusion at $75: 1 \mathrm{C} / \mathrm{N}$ ratio for 7 days. From this figure, it is clear that $25^{\circ} \mathrm{C}$ incubation temperature was favorable for the 
high production of Agaricus bisporus mycelium. While, $30^{\circ} \mathrm{C}$ was the most favorable temperature for the production of mycelium from Pleurotus ostreatus. On the other hand, Pholoita aegertia mycelium was produced with the highest $\mathrm{EC}$ when grown at $20^{\circ} \mathrm{C}$. The differences between the optimum temperatures may be attributed to the individual physiological properties of studied fungi (Gewaily, 1977).

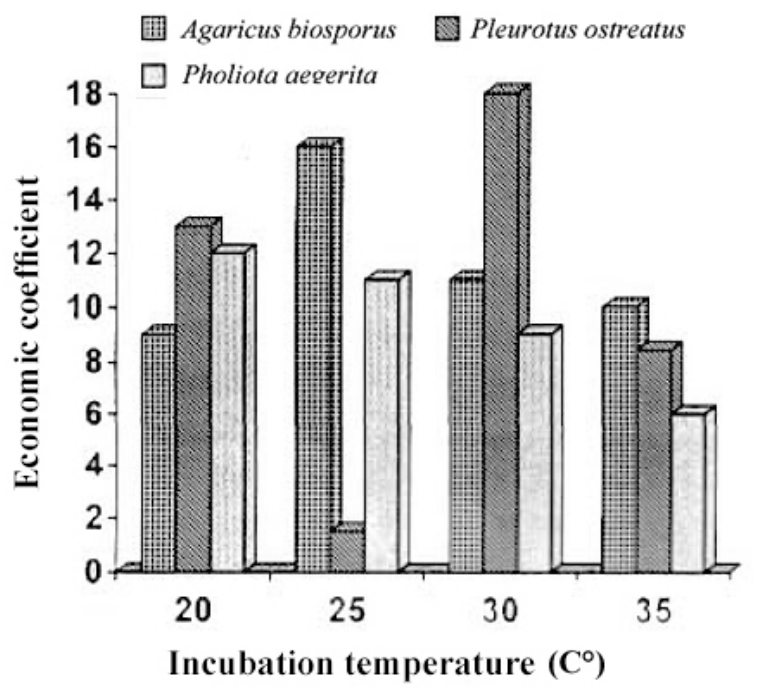

Fig. 1: Effect of incubation temperature on the economic coefficient of mushroom mycelia production

The effect of initial $\mathrm{pH}$ values on the economic coefficient of the produced mushroom mycelium grown in mango stone infusion at 75:1 C/N ratio for 7 days are illustrated in Fig. (2). From this figure, it could be observed that, the initial $\mathrm{pH}$ of the mango stone infusion medium had a pronounced effect on the production of mushroom mycelia. The favorable $\mathrm{pH}$ values for mushroom mycelia production with the highest EC by $A$. bisporus, Pl. ostreatus and Ph. aegerita were 4.0, 4.5 and 5.5, respec-tively. These results disagree with those obtained by Block et al. (1953) who mentioned that the original $\mathrm{pH}$ of the medium had very little effect on the total yield of mycelium produced by A. blozei grown in synthetic medium. They detected that the mycelium buffered the medium at approxi-mately $\mathrm{pH} 5.5$, in orange juice medium. Generally, changing the $\mathrm{pH}$ values towards acidity or alkalinity led to decrease the mycelium dry weight and EC. This could be attributed to (i) the production of small

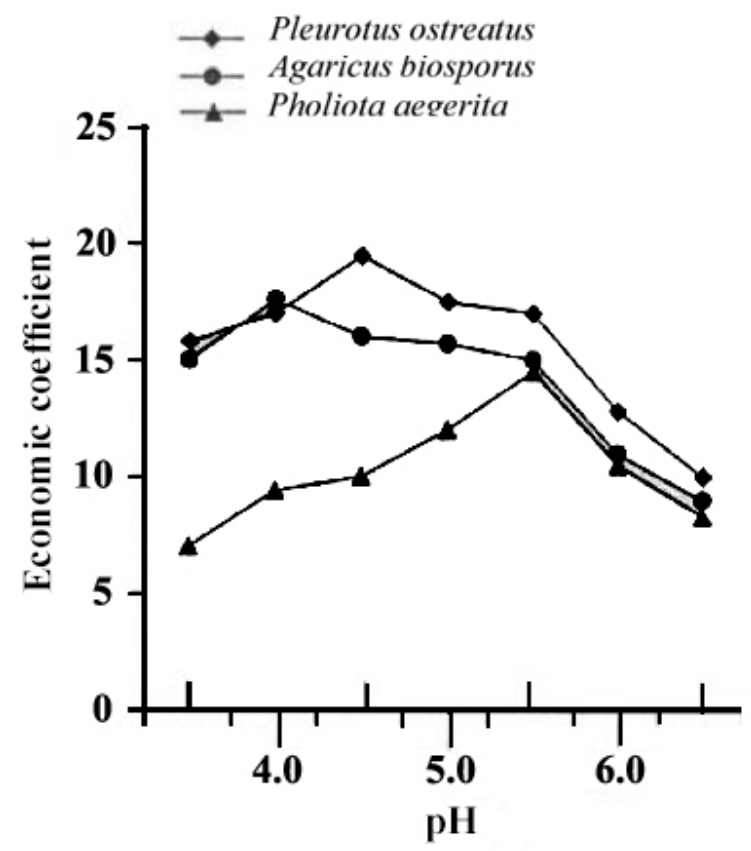

Fig. 2: Effect of different $\mathrm{pH}$ values on the economic coefficient of mushroom mycelia production

amount of organic acids like succinic acid produced during the growth, (ii) carbon dioxide produced by the cells and dissolved in the medium and/or (iii) use of the basic compounds such as ammonium tartrate by the cells (Yoshida et al., 1990).

The effect of shaking rate on the EC of produced mushroom mycelium grown in mango-stone infusion at $75: 1 \mathrm{C} / \mathrm{N}$ ratio for 7 days at the optimum temperature and $\mathrm{pH}$ for each fungus are shown in Fig. (3). The results indicated that the EC increased with increasing the shaking rate for the three studied mushrooms.

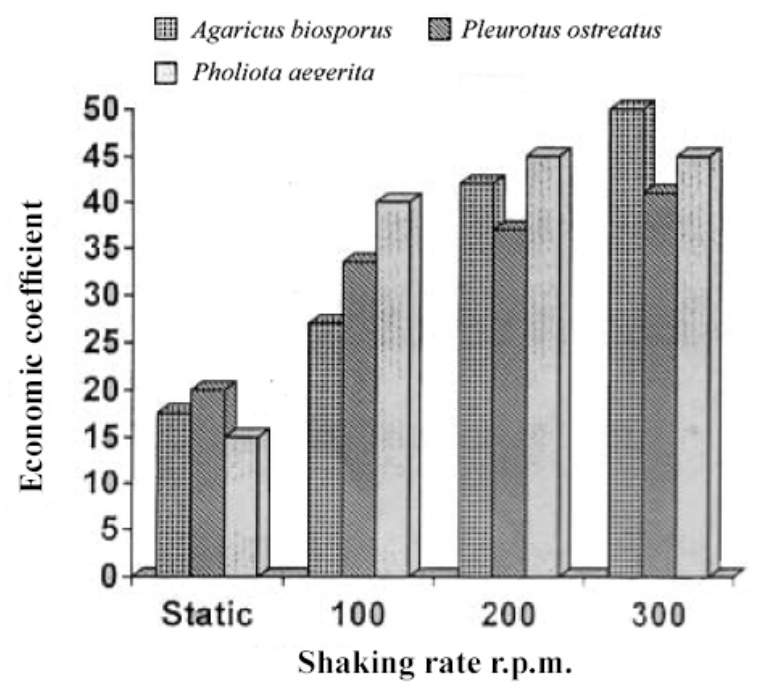

Fig. 3: Effect of shaking rate on the economic coefficient of mushroom mycelia production 
Economic coefficient were 49.2, 41.9 and 46.5 or for A. bisporus, Pl. ostreatus and Ph. aegerita at 300 r.p.m., respectively. On the other hand, EC were 17.4, 19.4 and 14.8 in static culture for studied fungi, respectively. There are no residual sugars in mango stone infusion media with increasing shaking rate and mycelia dry weight increased. Generally, these findings sounded to be true since, fungi are strictly aerobic. Nevertheless, the quantitative relation of growth and oxygen supply were very considerable among different forms (Wix \& Woodbine, 1959, Subba, 1989, Zhu \& Hi, 1999).

The effect of $\mathrm{C} / \mathrm{N}$ ratio on the economic coefficient of the produced mushroom mycelia from A. bisporus, Pl. ostreatus and $\mathrm{Ph}$ oegerita grown under the optimum conditions stated before in the present results are illustrated in Fig. (4). From this figure, it could be noticed that decreasing $\mathrm{C} / \mathrm{N}$ ratio by adding ammonium tartrate increased economic coefficient for all the three mushrooms studied. Moreover, the fungi consumed the total sugars in the media, while the mycelium increased, this reflects the ability of these fungi to utilize citric acid as a carbon source. Generally, high economic coefficient was 66.82 for $A$. bisporus followed by 63.88 and $51.92 \%$ in case of $P h$. aegerita \& $P$. ostreatus, respectively. These results are in line with those obtained by Yoshida et al. (1990), who found that the optimal carbon/ nitrogen ratio in the medium was 20:1 for production

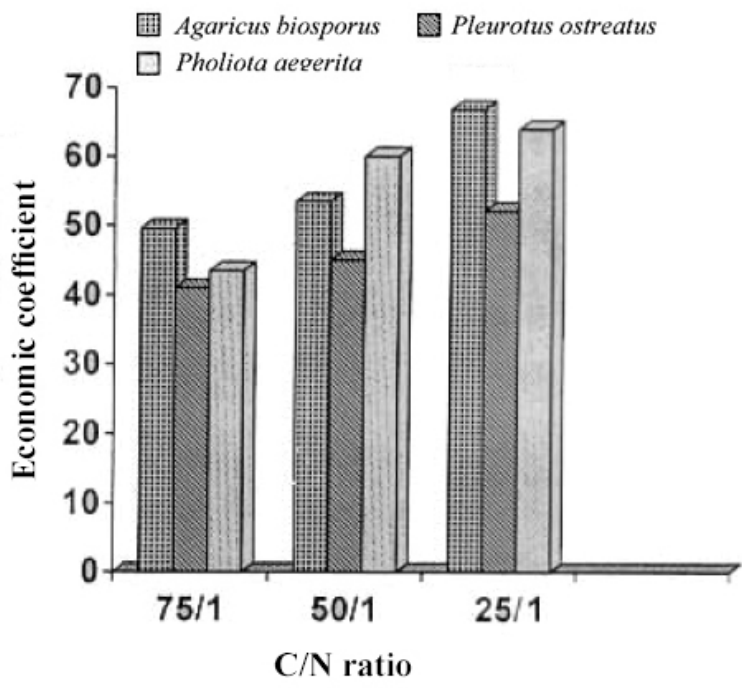

Fig. 4: Effect of $\mathrm{C} / \mathrm{N}$ ratio on the economic coefficient of mushroom mycelia production of A. compeotris, Morchela hybride mycelia when grown in liquid culture media.

Comparison between molasses and mango-stone infusion media on the production of mushroom mycelia from $\mathrm{A}$. bisporus, $\mathrm{Pl}$. ostreatus and $P h$. aegerita under the optimum conditions for each fungi are tabulated in Table (2). The EC obtained from molasses medium was lower than that from mango stone infusion medium for the three studied mushrooms. The EC for A. bisporus, Pl. ostreatus and Ph. aegrerita were 33.6, 39.0 and 43.4 in case of molasses media and 66.82, 51.92 and 63.88 in case of mango stone infusion, respectively. This may be attributed to the difference in nutrients between the molasses media and/or fermentable sugars abounding in each medium. On the contrary Reusser et al. (1958) cultured four strains of $A$. campeestris on a synthetic medium and on media containing molasses or waste sulfite liquor. They found that, high yields of dry matter and protein were obtained on molasses medium, while yields on waste sulfite liquor were slightly lowered. On the other hand, Falanghe (1962) observed that, A. compestris, and Tricholoma nudum were capable of growing in submerged culture in medium of vinasse with added salts. Higher fermentative efficiencies were found under these conditions than in medium containing molasses or waste sulfite liquour.

Table (3) shows the proximate analysis of the dried mycelium of three mushroom strains studied grown in mango stone infusion media. It was pointed that, the dry mycelium of $A$. bisporus showed a higher protein and fiber contents than either Pl. ostreatus or Ph. aegerita, while $P l$. ostreatus contained a higher fat and ash contents than either A. bisporus or Ph. aegerita. Carbohydrates content was higher in $P h$. aegerita than the other two strains studied. This may be due to the physiological properties during growth of these strains. These results are in accordance with findings of Cavazzoni \& Adami (1992) and Yoshida et al (1996).

The amounts of inorganic elements of the mushrooms mycelia grown at the optimum conditions for each in mango stone infusion are presented in Table (4). It was noticed that potassium and magnesium predominated over all the other elements. These elements followed by sodium and calcium. Trace elements (Zinc, Copper, Iron and Manganese) ranged between 0.43 and $19.6 \mathrm{mg} / 100 \mathrm{~g}$ dry wt. Cadmium as a heavy metal was not found in all the mush- 
Table 2: Comparison between molasses and mango stone infusion media on the production of mushroom mycelium under the optimum conditions for each

\begin{tabular}{|c|c|c|c|c|c|c|}
\hline \multirow{2}{*}{ Media } & \multicolumn{3}{|c|}{ Sugars $(\mathrm{g} / 100 \mathrm{ml})$} & \multirow{2}{*}{$\begin{array}{c}\text { Mycelium } \\
\text { dry wt } \\
\text { (g/100ml) }\end{array}$} & \multirow{2}{*}{$\begin{array}{l}\text { Yield co- } \\
\text { efficient }\end{array}$} & \multirow{2}{*}{$\begin{array}{l}\text { Economic } \\
\text { coefficient }\end{array}$} \\
\hline & Total & Residual & Consumed & & & \\
\hline \multicolumn{7}{|l|}{ Agaricus bisporus } \\
\hline Molasses & 5.00 & 0.29 & 4.71 & 1.78 & 37.79 & 35.60 \\
\hline Mango stone infusion & 4.43 & 0.00 & 4.43 & 2.96 & 66.82 & 66.82 \\
\hline \multicolumn{7}{|l|}{ Pleurotus ostreatus } \\
\hline Molasses & 5.00 & 0.18 & 4.82 & 1.95 & 40.46 & 39.00 \\
\hline Mango stone infusion & 4.43 & 0.00 & 4.43 & 2.30 & 51.92 & 51.92 \\
\hline \multicolumn{7}{|l|}{ Pholiota aegerita } \\
\hline Molasses & 5.00 & 0.62 & 4.38 & 2.17 & 49.54 & 43.40 \\
\hline Mango stone infusion & 4.43 & 0.00 & 4.43 & 2.83 & 63.88 & 63.88 \\
\hline
\end{tabular}

Table 3: Proximate analysis of dried mushroom mycelia grown in mango stone infusion media

\begin{tabular}{lccccc}
\hline Fungi & \multicolumn{2}{l}{ Composition (g/100g dry weight) } & & \\
\cline { 2 - 6 } & Carbohydrates & Protein & Fat & $\begin{array}{c}\text { Crud fi- } \\
\text { ber }\end{array}$ & Ash \\
\hline Agaricus bisporus & 40.92 & 31.60 & 7.60 & 10.7 & 4.18 \\
Pleurotus ostreatus & 48.28 & 24.50 & 8.00 & 7.0 & 6.22 \\
Pholiota aegerita & 50.19 & 26.90 & 7.30 & 9.3 & 3.39 \\
\hline
\end{tabular}

rooms under study, while lead content ranged between 0.03 and $0.07 \mathrm{mg} / 100 \mathrm{~g}$ dry wt. Differences between mushrooms for their ability to accumulate inorganic elements in their mycelium may be due to physiological properties itself and/or mineral content of the substrate before cultivation (Patrabnsh \& Madan, 1999). Low concentration of sodium and relatively high concentration of potassium suggest that mushroom mycelia may be useful as a potential anti-hypertensive food (Manzi et al., 1999).

Table 4: Inorganic elements in mushroom mycelia grown under its optimum conditions, in mango-stone infusion.

\begin{tabular}{lccc}
\hline \multirow{2}{*}{ Elements } & \multicolumn{3}{c}{$\begin{array}{c}\text { Element content (mg/100g dry wt.) } \\
\text { of mycelia }\end{array}$} \\
\cline { 2 - 4 } & $\begin{array}{c}\text { Agaricus } \\
\text { bisporus }\end{array}$ & $\begin{array}{c}\text { Pleurotus } \\
\text { ostreatus }\end{array}$ & $\begin{array}{c}\text { Pholiota } \\
\text { aegerita }\end{array}$ \\
\hline Calcium & 27.0 & 34.0 & 30.0 \\
Magnesium & 140.0 & 160.0 & 110.0 \\
Potassium & 368.0 & 460.0 & 250.0 \\
Sodium & 70.0 & 65.0 & 73.0 \\
\hline Copper & 16.5 & 6.0 & 7.3 \\
Iron & 5.3 & 5.9 & 4.2 \\
Manganese & 0.51 & 6.59 & 0.43 \\
Zinc & 19.6 & 11.0 & 7.0 \\
\hline Cadmium & 0.00 & 0.00 & 0.00 \\
Lead & 0.03 & 0.07 & 0.04 \\
\hline
\end{tabular}

\section{REFERENCES}

Allan, L. \& Kennedy, M. 1997. Production of natural mushroom flavour by submerged culture of mushroom mycelium. Food Technologist 27 (1): 25-28.

Anon, 1994. Hi-Tech mushroom pas export. Food Technology in New Zealand 29 (1): 12-14.

A.O.A.C. 1980. Official Methods of Analysis $13^{\text {th }}$ ed. Association of Official Analytical Chemists, Washington, DC, USA.

Ballero, M. 1991. Olive milling waste water as a medium for growth of four Pleurotus species. Appl. Biochemistry and biotechnology, 31 (3): 223-235.

Block, S., Sterns, T., Stephens, R. \& McCandless, R. 1953. Mushroom mycelium Experiments with submerged culture. J. Agr. Food Chem., 1: 890893.

Cavazzoni, V. \& Adami, A. 1992. Exopolysaccharides produced by mycelial edible mushrooms. Italian J. Food Science, 4 (1): 9-15. [c.f., FSTA 24 (8) 8j 139].

Chiang, B., Chu, C., \& Hwang, L. 1986. Mushroom blanch water concentration by membrane processes J. Food Sci., 51 (6): 608613.

Cirillo, V. 1960. Fermentation process for producing edible mushroom mycelium U.S. Patent 2, 928.210 c.f.: Falanghe, H. (1962). 
Ethiraj, S. \& Suresh, R. 1992. Studies on the utilization of mango processing wastes for production of vinegar. J. Food Science and Technology, India 29 (1): 48-50.

Falanghe, H. 1962. Production of mushroom mycelium as a protein and fat source in submerged culture in medium of vinasse. Appl. Microbiology, 10: 572-567.

Gewaily, E. 1977. Studies on mycological fat production. Annals of Agriculture Sci. Moshtohor, 7: 31-36.

Hadar, Y. \& Dosoretz, G. 1991. Mushroom mycelium as a potential source of food flavour. Trends in Food science \& Technology, 2 (9): 214-218.

Johl, P., Sodhi, H. \& Kapoor, S. 1997. Mushroom as medicine (Review). J. Plant Science Research 11 (4): 73-80.

Joshi, C. \& Joshi, K. 1990. Food processing waste management technology need for an integrated approach. Indian Food Packer, 44 (5): 50-57.

Kalac, P. \& Svoboda, L. 2000. A review of trace element concentration in edible mushroom. Food Chemistry 69 (3): 273-281.

Kuniori, T., Nishiyama, J. \& Matsumoto, H. 1976. Effect of mushroom extract on the physical properties of dough. Cereal Chemistry, 53: 420-428.

Kuzmanova, S., Vandeska, C. \& Dimitrovski, A. 1991. Production of mycelial protein and cellulolytic enzymes from food wastes J. Industrial Microbilogy, 4 : 257-261.

Litchfield, G., Vely, V. \& Overback, R. 1963. Nutrient content of moral mushroom mycelium. J. Food Sci., 28: 741-743.

Manzi, P., Gambelli, L, Marconi, S. \& Pizzoferrato, L. 1999. Nutrients in edible mushroom: comparative study. Food Chemistry 65 (4): 477-482.
Patrabnsh, S. \& Madan, M. 1999. Mineral content of Pleurotus sajorcaju cultivated on different Kinds of biomass. Acta Biotechnologica 19 (2): 101-109.

Reusser, F., Spencer, J. \& Sallans, H. 1958. Protein and fat content of some mushrooms grown in submerged culture. Appl. Microbiol., 6: 1-4.

Somgyi, M. 1945. A new reagent for the determination of sugars J. Biol. Chem. 160: 61-68.

Subba, N. 1989. Advances in Agricultural Microbiology. Oxford \& IBH Publishing Co. New Dalhi.

Sugihara, T. \& Humfeld, H. 1954. Submerged culture of the mycelium of various species of mushroom, Appl. Microbiology 2: 170172.

Wix, P. \& Woodbine, M. 1959. Mycological synthesis of fat from whey. 11-comparative studies with shaken and stationary cultures using selected moulds. J. Appl. Bact., 22: 175-178.

Yoshida, H., Fujimoto, S. \& Hayashi, J. 1990. Studies on the physiological and chemical characteristics of kuritake mushroom (Naematoloma sublateritium). J. Japanese Society of Food Sci. and Technology, 37 (9): 695-701. [c.f.: FSTA 23 (5): 5 J 213$1991]$.

Yoshida, H., Sasaki, H., Fujimoto, S. \& Sugahara, T. 1996. The chemical components of the vegetative mycelia of basidiomycetes J. Japanese Society of Food Science and Technology 43 (6): 748-755.

Zhu, H. \& Hi, G. 1999. Nutritional conditions for submerged culture of Flammulina velutipes in starch pressing waste water. Chinese J. Biotechnology 15 (4): 512-516. 


\section{تنمية ثلاثة أجناس من عيش الفراب

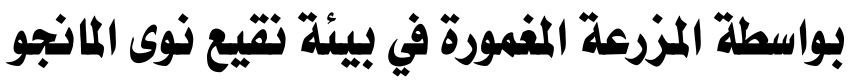

علية محمد علية المخزنجي

قuم التصنيع الزراعي معهد الكفاية الإنتلجية - -جلمعة الزقازيق

مُ درلسة العوال المؤثرة على إنتاج هفلت عيش الغراب من الططريت التالية : Agaricus bisporus

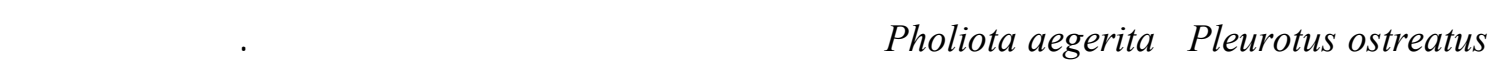

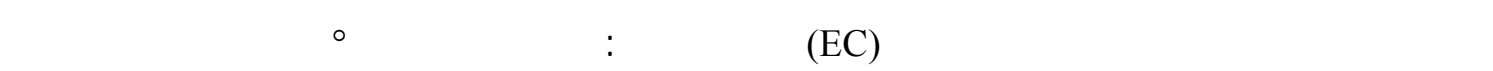

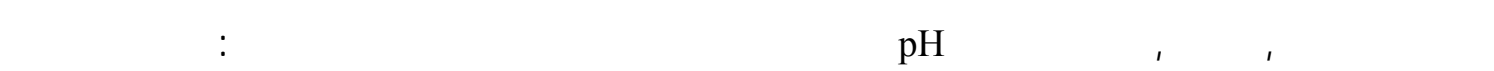

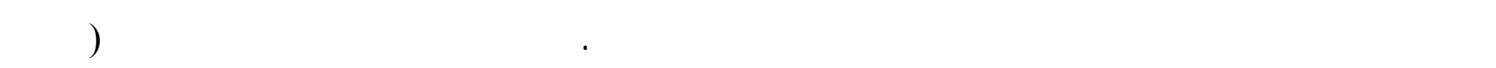

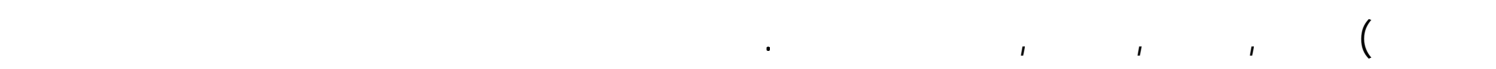

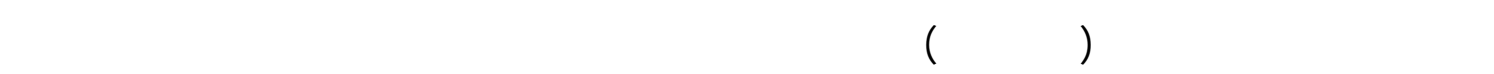

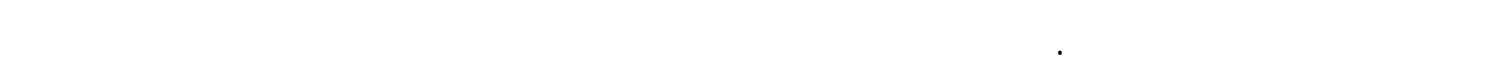

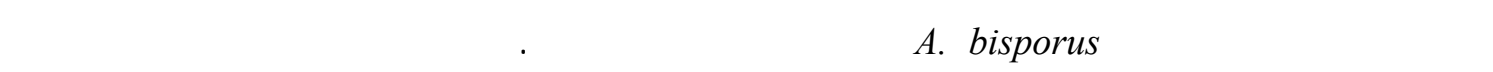

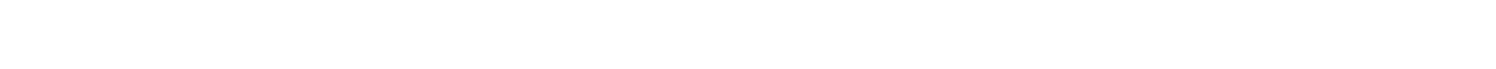
الميسليوم الجلف للنطريات الثلاثة موضع الدربلة. 